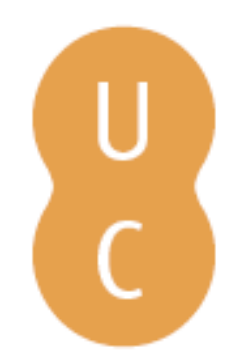

\title{
nommalina
}

\section{Modeling the probability of impact from wildland fires: a near real-time approach}

Autor(es): $\quad$ Cardil, Adrián; Ramirez, Joaquin; Monedero, Santiago

Publicado por: Imprensa da Universidade de Coimbra

URL

persistente: URI:http://hdl.handle.net/10316.2/44703

DOI: $\quad$ DOI:https://doi.org/10.14195/978-989-26-16-506_186

Accessed : $\quad$ 26-Apr-2023 11:57:10

A navegação consulta e descarregamento dos títulos inseridos nas Bibliotecas Digitais UC Digitalis, UC Pombalina e UC Impactum, pressupõem a aceitação plena e sem reservas dos Termos e Condições de Uso destas Bibliotecas Digitais, disponíveis em https://digitalis.uc.pt/pt-pt/termos.

Conforme exposto nos referidos Termos e Condições de Uso, o descarregamento de títulos de acesso restrito requer uma licença válida de autorização devendo o utilizador aceder ao(s) documento(s) a partir de um endereço de IP da instituição detentora da supramencionada licença.

Ao utilizador é apenas permitido o descarregamento para uso pessoal, pelo que o emprego do(s) título(s) descarregado(s) para outro fim, designadamente comercial, carece de autorização do respetivo autor ou editor da obra.

Na medida em que todas as obras da UC Digitalis se encontram protegidas pelo Código do Direito de Autor e Direitos Conexos e demais legislação aplicável, toda a cópia, parcial ou total, deste documento, nos casos em que é legalmente admitida, deverá conter ou fazer-se acompanhar por este aviso. 


\section{ADVANCES IN}

\section{FOREST FIRE RESEARCH}

\section{8}

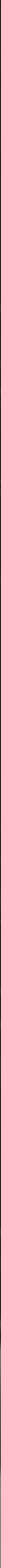


Short contribution - Decision Support Systems and Tools

Modeling the probability of impact from wildland fires: a near real-time approach

\author{
Adrián Cardil $^{1 *}$; Joaquin Ramirez ${ }^{2}$; Santiago Monedero ${ }^{1}$ \\ I* Tecnosylva. Parque Tecnológico de León. 24009 León, Spain, \{acardil@tecnosylva.com*. \\ smonedero@tecnosylva.com\} \\ ${ }^{2}$ Technosylva.UCSD Calit2 Qualcomm Institute.La Jolla, CA 92037, \{jramirez@technosylva.com\}
}

Keywords: fire behaviour, fire modelling, Wildfire Analyst,

\title{
1. Background
}

Large and intense wildfires burn millions of hectares annually, impacting societies worldwide. Environmental, social, and economic impacts can reach catastrophic levels, particularly where human populations interact closely with natural and managed landscapes in fire prone areas. While fire professionals work to protect ecological and human resources during fire suppression, personnel are frequently challenged by the complexity of controlling wildfires in wildland urban interfaces. Protecting firefighters, citizens, homes, environmental, and economic resources is made more complex by the need to prioritize limited wildfire suppression personnel and equipment to address changing wildfire conditions. The ability to estimate the probability of a wildfire reaching an area where these resources are most vulnerable is critically important to preventing loss of human life and property, and damage to ecological and economic assets. We present an innovative probabilistic fire simulation mode of the Wildfire Analyst (WFA) software; an approach to simulate fire inversely while considering uncertainties in input data.

\section{Exposure probabilistic analysis}

This mode can assess the time and probability that a fire will reach a vulnerable area, by simulating (n) evacuation simulations with varying input data according to a potential range of deviations added by the analyst in near real-time. The evacuation method is also available in WFA software and is based on a fire inverse travel time mode technique that allows computing $\mathrm{x}$-hour firesheds around valuable assets or evacuation points. This propagation mode computes the time that a standard simulation starting at any point of the landscape would take to spread to a set of user defined points (for instance, a wildland urban interface area, infrastructures, assets, etc), instead of showing the usual time a fire would take to spread from a set of user defined ignition points to any point of the landscape.

\section{Where has this method implemented?}

The method is already implemented in WFA software and can be applied by fire analysts worldwide. We show in Figure 1 the Vall d'Ebo Fire (Spain, 2015) using Rothermel's model as the underlying surface fire spread engine. Simulated fire growth showed a good agreement with the final fire perimeter as shown in Figure 1a. To test the exposure probabilistic method in this fire, we run 100 evacuation simulations considering weather predictions before starting the fire, dealing with weather uncertainties by using a range of variation of those more influencer input variables on fire behavior and spread. We used a range of variation of $3 \mathrm{~km} / \mathrm{h}$ for wind speed, $30^{\circ}$ for wind direction and $1 \%$ for fine fuel moisture content (1h). 
a)

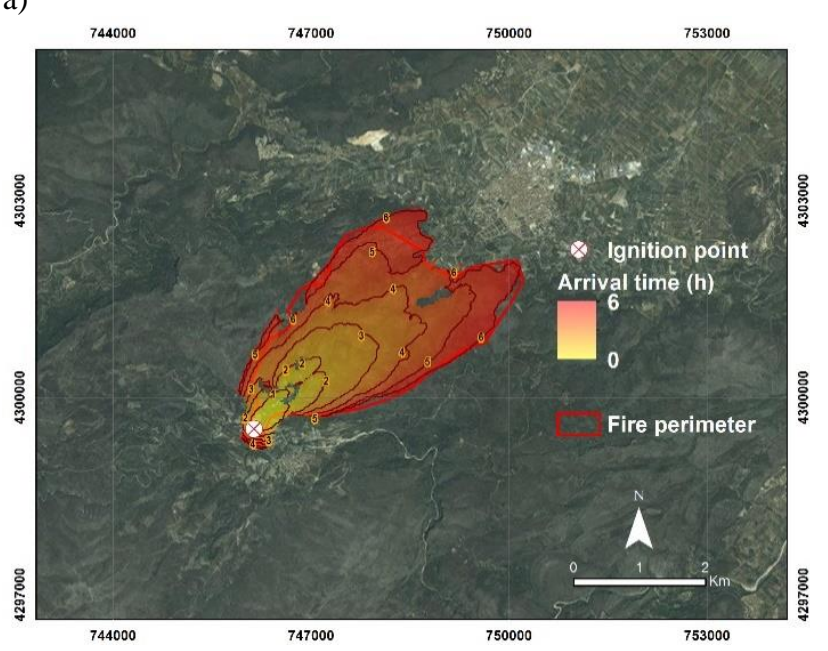

b)

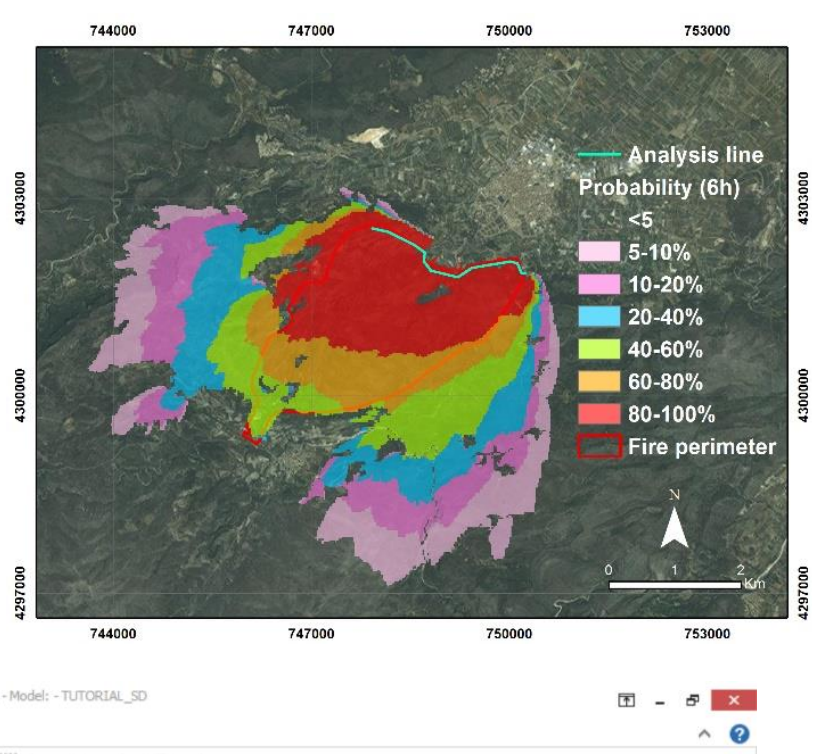

c)

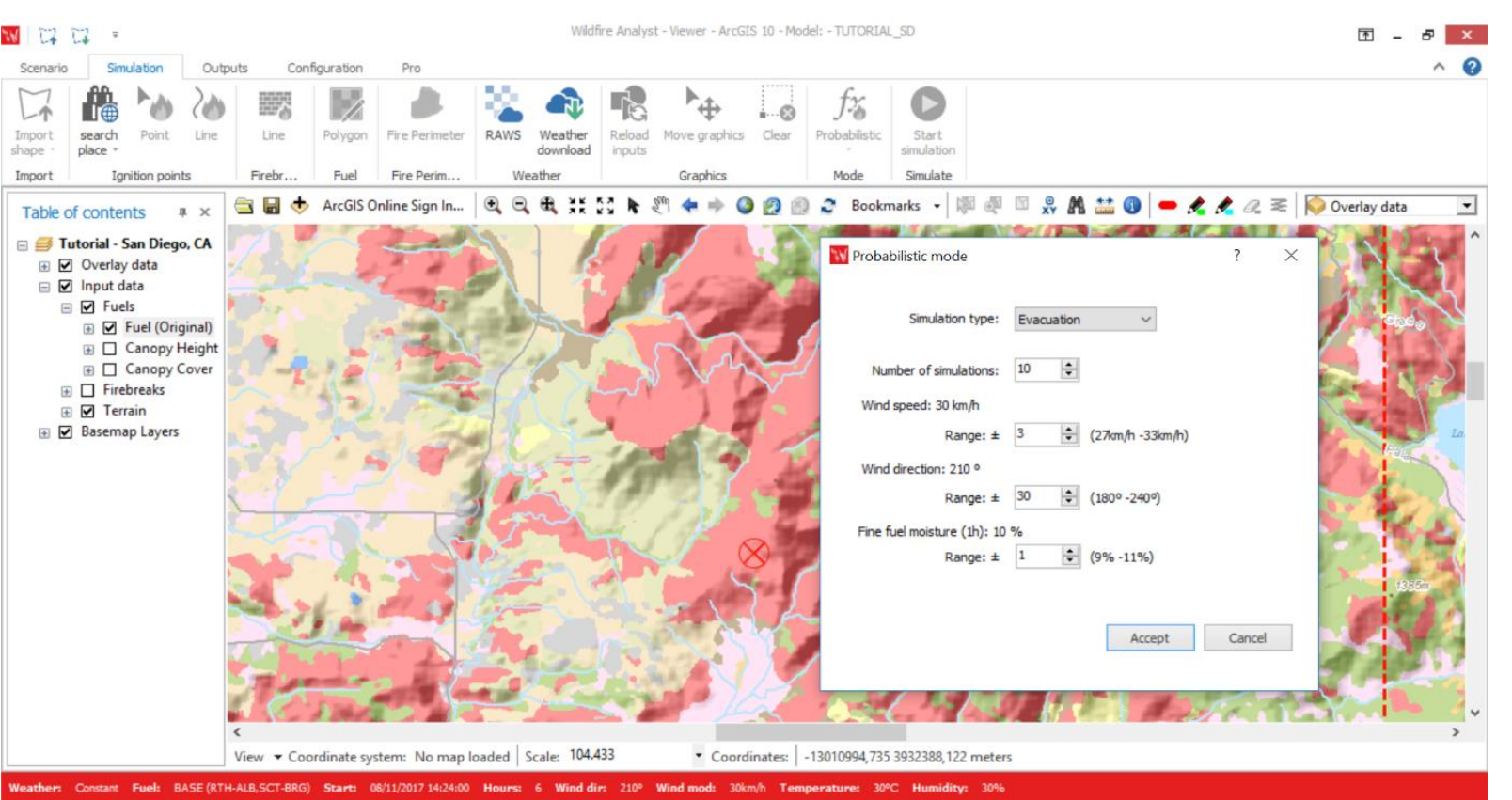

Figure 1 - Vall d'Ebo (Spain, 2015) fire simulation and real fire perimeter in the first 6 hours. a) Forward in time fire simulation from the ignition point; $b$ ) Probabilistic evacuation mode considering the edge of the wildland urban interface (Analysis line), running 100 fire evacuation simulations with a duration of 6 hours; $c$ ) WFA interface for the Exposure Probabilistic Analysis

\section{Implications for fire management.}

The exposure probabilistic mode provides a perfect framework for analyzing suppression actions in the WUI or vulnerable assets in near real-time and allows decreasing the uncertainty of the fire analyst in the decision-making process. By identifying structures or wildland communities this mode will determine the time of arrival for each location identified providing a baseline for evacuation planning. Additionally, this tool can be used to optimize fuel treatment location and quantify fire behavior and spread near WUIs. Towards the development of effective fire management operational systems, the use of fire behavior and spread models and decision support planning modules such as FireResponse (Technosylva, Inc) plays an important role. Today's firefighting needs demand systems that are able to conduct on a timely manner fire behavior predictions for several different users of fire suppression and civil protection agencies involved. In this sense, both the algorithms and methods that we show in this work can be solved in real-time in a few seconds and the mode is already implemented in WFA. 